Original Research Paper

\title{
Pengenalan Pestisida Nabati Dari Limbah Batang Tembakau Virginia Untuk Mengendalikan Hama Kutu Kebul (Bemisia Tabaci) Pada Tanaman Kentang
}

\author{
M. Sarjan ${ }^{1}$, Moh Taufik Fauzi ${ }^{1}$, Ruth Stella P. Thei ${ }^{2}$, dan Mery Windarningsih ${ }^{2}$ \\ 1 Pascasarjana Universitas Mataram, Mataram, Indonesia \\ ${ }^{2}$ Program Studi Agroekoteknologi, Fakultas Pertanian, Universitas Mataram, Indonesia
}

DOI: https://doi.org/10.29303/jpmpi.v3i2.508

Sitasi : Sarjan, M., Fauzi, M. T., Thei, R. S. P., \& Windraningsih, M. (2020). Pengenalan Pestisida Nabati Dari Limbah Batang Tembakau Virginia Untuk Mengendalikan Hama Kutu Kebul (Bemisia Tabaci) Pada Tanaman Kentang. Jurnal Pengabdian Magister Pendidikan IPA, 3(2)

\section{Article history}

Received: 29 September 2020

Revised: 25 Oktober 2020

Accepted: 19 November 2020

*Corresponding Author:

M. Sarjan,

Pascasarjana, Universitas

Mataram, Mataram, Indonesia; Email: msarjan@unram.ac.id
Abstract: Salah satu alternatif teknologi pengendalian hama yang cukup menjanjikan untuk dikembangkan adalah penggunaan pestisida nabati yang lebih bercirikan alami daripada ciri kimiawi. Dengan sifat-sifatnya yang mudah terurai, aman bagi kesehatan manusia dan lingkungan hidup, dapat diharapkan bahwa produk-produk pertanian yang diperlakukan dengan pestisida nabati dapat diterima dan berdaya saing tinggi di pasar global. Bahan-bahan nabati dapat diperoleh dari berbagai tumbuhan. Disamping itu, ada beberapa yang dapat diperoleh dari limbah pertanian seperti limbah batang tembakau virginia. Produk pestisida dari bahan limbah tembakau Virginia tersebut telah dihasilkan oleh tim penelitian Fakultas Pertanian Universitas Mataram dengan nama Pestisida Nabati BT., yang telah diuji terhadap hama dari ordo Lepidoptera seperti Spodoptera litura pada tanaman kedelai. Dengan memanfaatkan petisida nabati tersebut diharapkan peranan musuh alami menekan hama akan meninghkat, sehingga penggunakaan pestisida kimia dapat dikurangi. Dengan demikian hasil yang diperoleh akan meningkat secara kuantitatif dan kualitatif dan akhirnya efisiensi dalam proses produksi akan tercapai dan keuntungan petani akan meningkat. Intervensi pemanfaatan teknologi kepada petani sebagai salah satu alternative dalam Pengelolaan Hama, terutama kutu kebul ( Bemisia tabaci) merupakan serangga hama vector penular penyakit virus pada budidaya kentang. Hasil pengabdian menunjukkan bahwa sebenarnya petani kentang sudah mengenal beberapa pestisida nabati dari berbagai bahan baku local, Petani sangat tertarik memanfaatkan limbah batang tembakau Virginia yang melimpah di pulau Lombok, dan berharap akan mampu menjadi alternative untuk mengurangi ketergantungan penggunaan pestisida kimia di kawasan agrowisata Sembalun.

Kata Kunci: Open Defecation Free (ODF), Kader desa, Perilaku hidup sehat 


\section{Pendahuluan}

Cembalun merupakan kawasan di lembah gunung - Rinjani merupakan kawasan yang sangat potensial untuk budidaya hortikultura dataran tinggi. Sejak lama daerah ini telah dikenal dengan berbagai komoditas sayuran seperti bawang putih, kentang, tomat, sawi, brokoli, pitsay, kubis , paprika, serta tanaman buah seperti strobery dan melon. Pada decade tahun 1980 an Sembalun pernah menjadi pusat produksi bawang putih nasional yang saat itu dikunjungi oleh Presiden Suharto. Sejak saat itu terjadi perubahan yang drastis dalam budidaya tanaman terutama menggunakan input produksi seperti pupuk dan pestisida kimia yang sangat intensif. Kebiasaan ini berlanjut sampai sekarang yang dikhawatirkan akan sangat mengganggu kualitas produk dan lingkungan di kawasan tersebut. Hal ini sangat menghawatirkan manakala kawasan ini sudah dijadikan sebagai pusat agrowisata di Pulau Lombok yang membutuhkan persyaratan kualitas produk untuk para kumsumen. Oleh karena itu secara bertahap harus diupayakan perubahan prilaku yang tergantung pada pestisida kimia beralih dengan memanfaatkan teknoligi alternative yang lebih ramah lingkungan seperti pemanfaatan pestisida nabati. Hal ini diharapkan bisa mengurangi dampak negative yang telah terjadi di kawasan tersebut, sehingga sasaran Sembalun sebagai kawasan Agrowisata yang ramah lingkungan akan terwujud.

Organisme Pengganggu Tumbuhan (OPT) adalah salah satu faktor pembatas dalam usaha budidaya tanaman sayuran. Kekhawatiran yang berlebih terhadap OPT biasanya mendorong penggunaan pestisida dengan efikasi tinggi, tanpa memperhitungkan dampak negatifnya terhadap lingkungan. Namun demikian, dengan meningkatnya kesejahteraan masyarakat, kesadaran akan kesehatan diri dan kelestarian lingkungan membuat tuntutan masyarakat akan kualitas bahan makanan dan lingkungan hidup makin meningkat. Hal ini terlihat dari berbagai kegiatan pertanian seperti munculnya kegiatan pertanian organik dan penerapan teknologi Pengendalian Hama Terpadu (PHT).

Tuntutan pasar dan kemajuan teknologi serta kesadaran masyarakat akan kesehatan dan lingkungan, dapat mendorong petani untuk mengenal dan mengembangkan konsep dan program pengendalian hama terpadu (PHT). Konsep tersebut telah berkembang di hampir semua negara, walaupun masih terdapat perbedaan yang signifikan dalam penerapannya antara negara berkembang dengan negara maju. Salah satu potensi yang dimiliki oleh negara tropis seperti Indonesia adalah keragaman hayati flora dan fauna yang dapat dimanfaatkan sebagai agen pengendali hama, seperti pemanfaatan insektisida nabati yang dapat diperoleh dari berbagai sumber flora. Pemanfaatan bahan nabati sebagai pengendali hama sudah lama dikenal, namun sudah banyak tergeser dengan pesatnya perkembangan teknologi industri pestisida kimia, terutama sejak revolusi hijau.

Salah satu alternatif teknologi pengendalian hama yang cukup menjanjikan untuk dikembangkan adalah penggunaan pestisida nabati yang lebih bercirikan alami daripada ciri kimiawi. Dengan sifat-sifatnya yang mudah terurai, aman bagi kesehatan manusia dan lingkungan hidup, dapat diharapkan bahwa produk-produk pertanian yang diperlakukan dengan pestisida nabati dapat diterima dan berdaya saing tinggi di pasar global. Bahan-bahan nabati dapat diperoleh dari berbagai tumbuhan. Disamping itu, ada beberapa yang dapat diperoleh dari limbah pertanian seperti limbah batang tembakau virginia. Produk pestisida dari bahan limbah tembakau Virginia tersebut telah dihasilkan oleh tim penelitian Fakultas Pertanian Universitas Mataram dengan nama Pestisida Nabati BT. VIRGINIA ( Sarjan, et al, 2019), yang telah diuji terhadap hama dari ordo Lepidoptera seperti Spodoptera litura pada tanaman kedelai ( Sarjan et al, 2012)

Dengan memanfaatkan petisida nabati tersebut diharapkan peranan musuh alami menekan hama akan meninghkat, sehingga penggunakaan pestisida kimia dapat dikurangi. Dengan demikian hasil yang diperoleh akan meningkat secara kuantitatif dan kualitatif dan akhirnya efisiensi dalam proses produksi akan tercapai dan keuntungan petani akan meningkat. Intervensi pemanfaatan teknologi kepada petani sebagai salah satu alternative dalam Pengelolaan Hama kutu kebul pada budidaya kentang Tujuan Kegiatan ini adalah 1) Mengenalkan pestisida nabati dari limbah batang tembakau virginia sebagai teknik alternatif dalam pengendalian OPT yang ramah lingkungan 2) Memotivasi peningkatan kemampuan dan pembentukan sikap petani untuk 
mengembang teknik alternatif selain pestisida kimia dalam mengendalikan Hama 3) Meningkatkan kesadaran petani akan arti pentingnya pengendalian hama dan penyakit tumbuhan untuk menghasilkan produk yang sehat 4) Meningkatkan penge tahuan petani tentang perlunya upaya mengurangi penggunaan pestisida kimia dalam budidaya tanaman kentang

Dari hasil kegiatan ini diharapkan dapat memberikan pemahaman dan keterampilan bagi petani sayuran di lokasi kegiatan dalam mencari cara alternatif selain pestisida kimia untuk mengendalian hama secara berkelanjutan. Selanjutnya akan meningkatkan motivasi bagi petani untuk menghasilkan produk sayuran yang sehat khususnya tanaman kentang dengan proses produksi yang ramah lingkungan, sehingga akan diperoleh peningkatan nilai tambah produk sayuran yang slanjutnya akan meninkatkan pendapatan petani kentang tersebut

\section{Metode}

1. Penentuan Lokasi Kegiatan dan Target Peserta

Kegiatan ini dilaksanakan di Kawasan Agrowisata Sembalun Kabupaten Lombok Timur, dan lokasi yang dipilih adalah Desa yang merupakan sentra kentang. Peserta terdiri atas petani yang tanamannya sedang atau pernah terserang organisme pengganggu tanaman.

2. Metode Pendekatan

Metode yang digunakan dalam kegiatan ini adalah Metode Kaji Tindak (Action Research) dengan menerapkan pendekatan Program Tindak Partisipatif (Partisipatory Action Program) dari peserta melalui diskusi, dan kerja kelompok pada seluruh kegiatan. Tahapan dalam kegiatan ini meliputi tahapan persiapan, antara lain identifikasi masalah, kemudian survey pendasaran menggunakan metode deskriptif eksploratif. Tahapan pelaksanaan, diawali dengan pelatihan dengan teknik ceramah. Materi pelatihan yang disampaikan meliputi Teknik Budidaya Tanaman kentang ; Pengenalan Organisme Pengganggu Tanaman kentang, serta Teknikteknik Pengendalian Organisme Pengganggu Tanaman.

3. Penilaian/evaluasi
Penialaian terhadap kegiatan pengabdian
pada masyarakat ini dilakukan dengan berpedoman pada :

a. Kesesuaian antara topik action research yang dilaksanakan dengan keadaan lokasi kegiatan.

b. Kehadiran dan partisipasi para peserta (sasaran) terhadap setiap kegiatan sejak dari persiapan sampai berakhirnya kegiatan mencerminkan keinginan dari peserta untuk mengetahui dan mengadopsi teknologi yang diperkenalkan oleh Tim pelaksana.

c. Sikap dan tanggapan dari para peserta terhadap kegiatan yang dilaksanakan.

\section{Hasil dan Pembahasan}

\section{Kegiatan Ceramah dan Diskusi}

Pada kegiatan pengadian ini, sebelum dilakukan demonstrasi pembuatan pestisida nabati dari batang tebakau Virginia, peserta diberikan penjelasan umum tentang pengendalian hama kentang menggunakan pestisida nabati, termasuk pemanfaatan limbah batang tembakau Virginia. Anggota kelompok yang hadir sebagian besar unsur pemuda yang telah mulai menerapkan teknik alternative pengendalia hama dan beberapa orang telah menerapkan budidaya pertanian organic. Para peserta diskusi sangat bersemangat mendengarkan dan mencermati penyampaian materi yang dibawakan oleh Tim. Di sampng dapat dilihat dari kehadiran peserta, juga dari interaksi peserta dengan Tim selama diskusi, para peserta banyak menanyakan hal hal yang berkaitan dengan pengalaman mereka di lapangan, terutama berkaitan dengan teknik pengendalian hama 


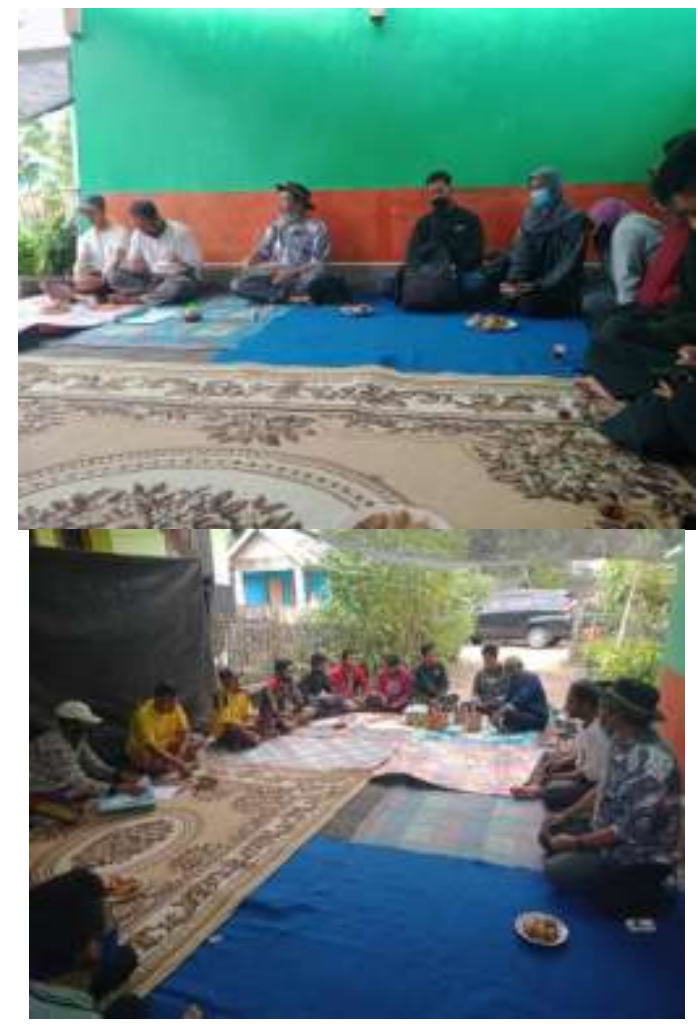

Gambar 1. Ceramah dan diskusi antara Tim dengan peserta ( kelomok Tani)

\section{Pembuatan Pestisida Nabati dari limbah batang tembakau Virgnia}

Pada pembuatan larutan dasar pestisida dari limbah batang tembakau Virginia, peserta dijelaskan bahan da alat yang digunakan serta bagaimana cara kerja dan prolses mulai dari awal sampai diperoleh larutan dasar yang siap digunakan . Pada demonstrasi ini digunakan 4

konsentrasi yang berbeda yaitu 100, 200, 300 dan 400 gram bahan batang tembakau yang telah dicacah per liter air. Bahan perekat yang dugunakan adalah detergen sebayak 1 sendok the, kemudian larutan yang diperoleh disimpan dalam botol aqua selama paling sedikit 1 malam sebelum digunakan.

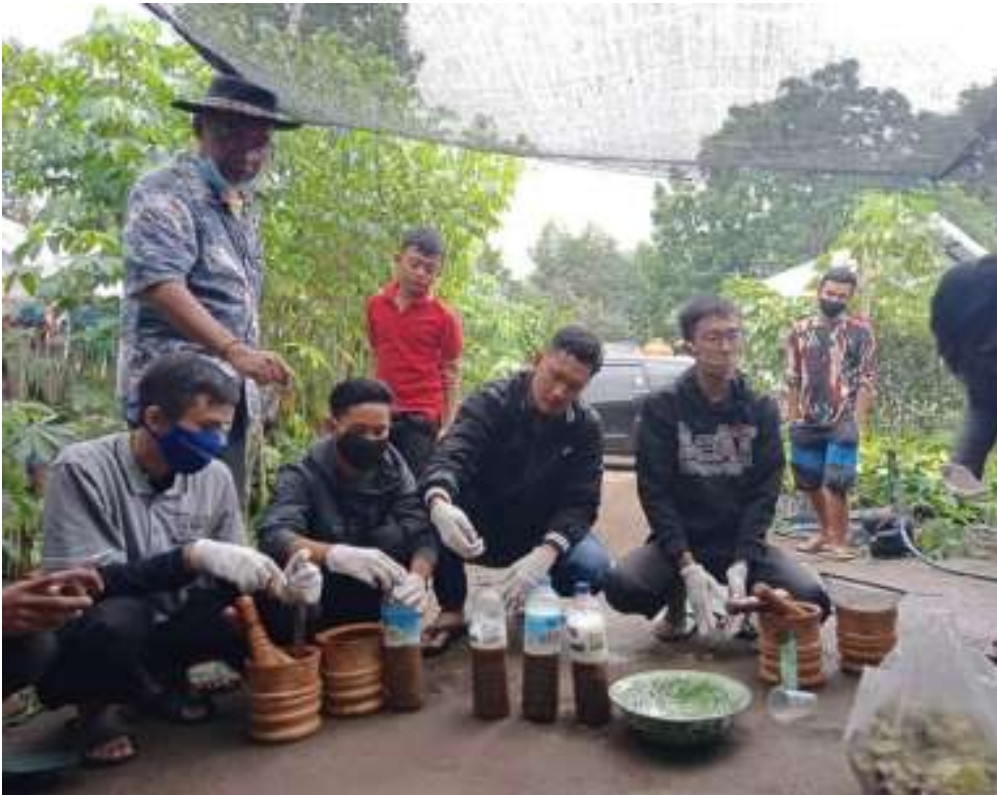

Gambar2. Proses Pembuatan Larutan dasar Pestisida dari limbah batang tembakau Virginia

\section{Penanaman Tanaman Kentang , Pemeliharaan dan Pengendalian Hama}

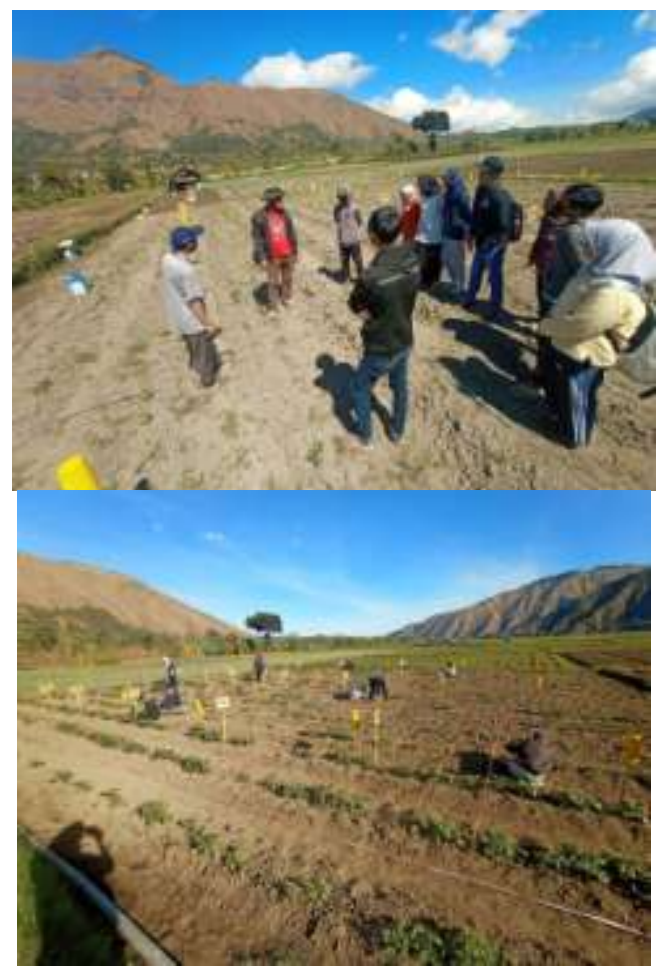

Gambar3. Persiapan penanaman kentang 


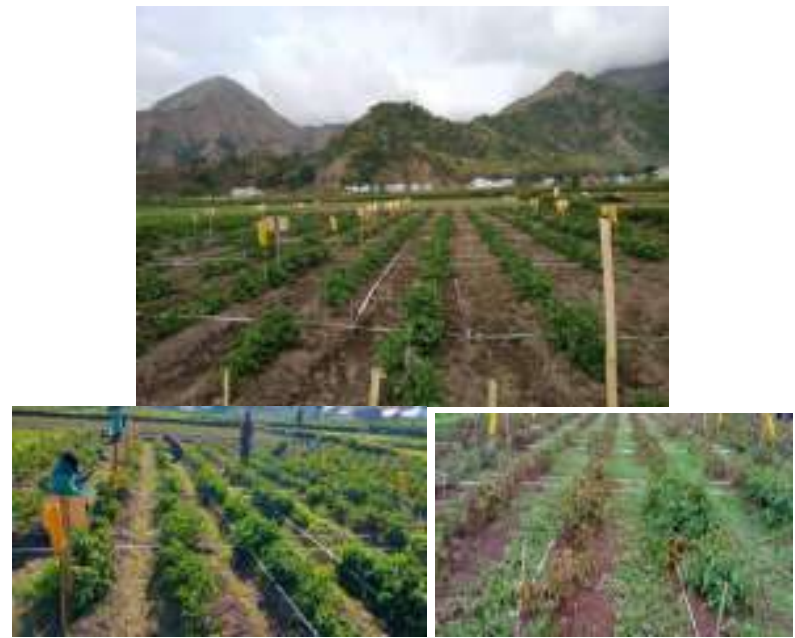

Gambar 4. Pemeliharaan tanaman dan Pengamatan hama

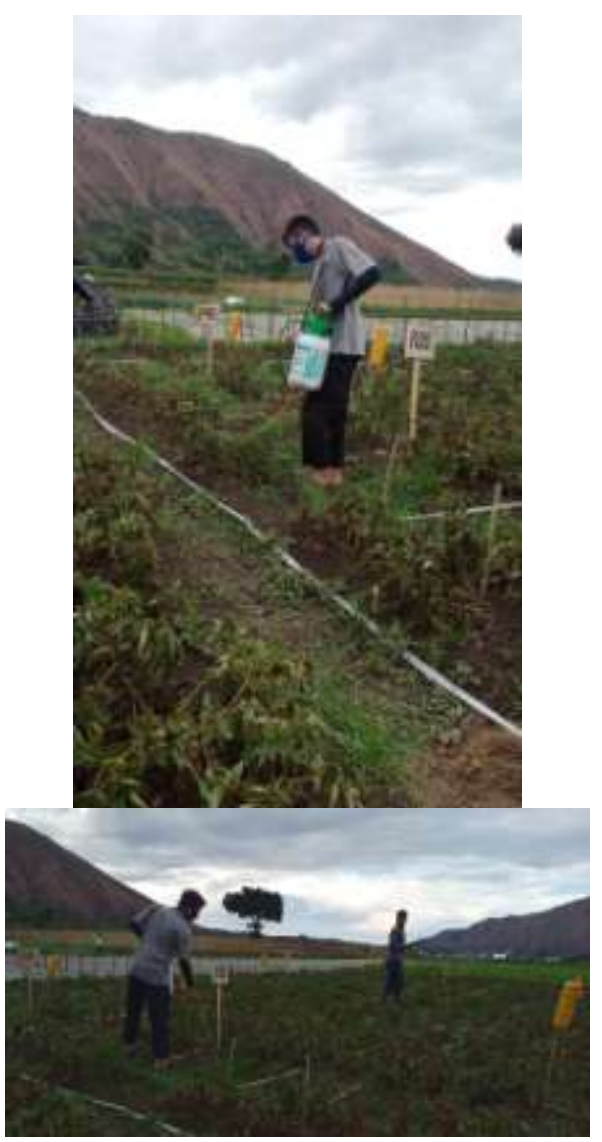

Gambar 5. Penyemprotan tanaman menggugunakan petisida nabati

\section{Kegiatan Pengamatan dan Hasil Pengamatman}

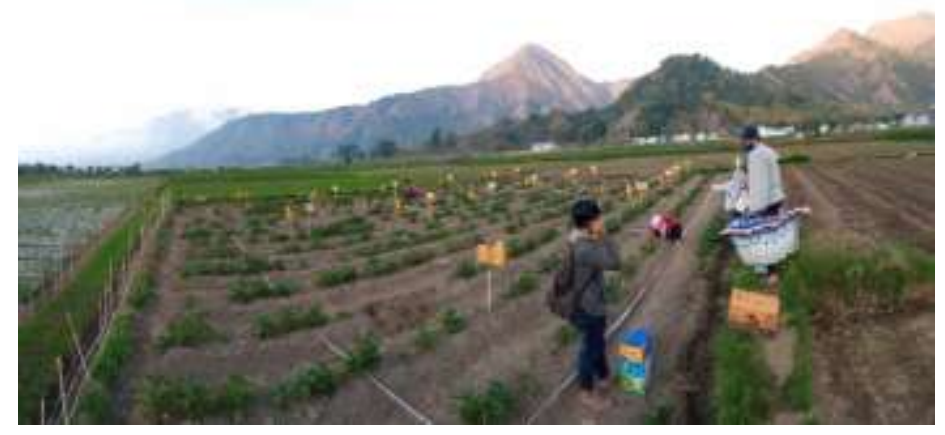

\section{Gambar 6 : Persiapan Penyemprotan sehari} sebelum pengamatan

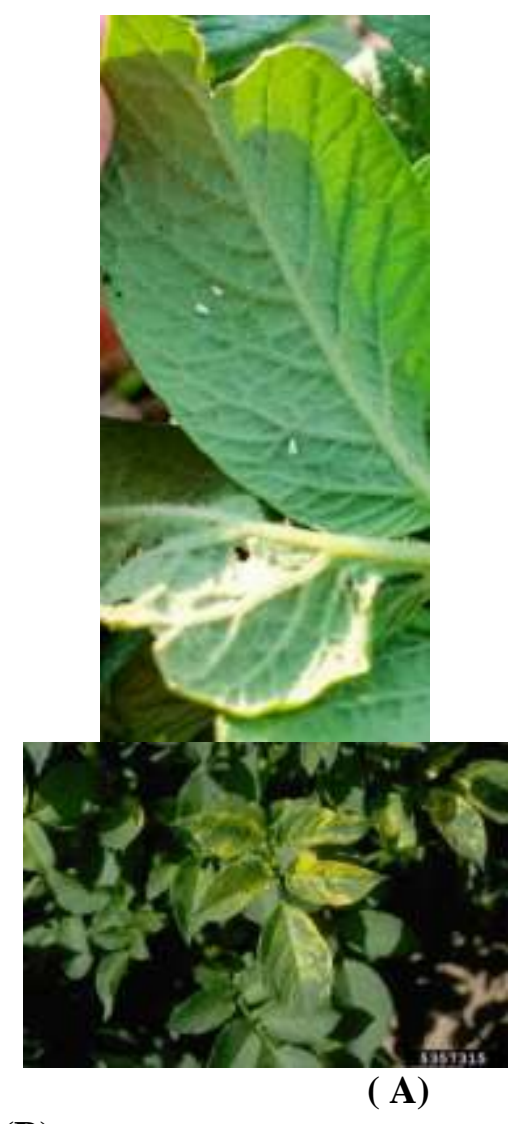

(B)

Gambar 7: Hama kutu kebul (Bemisia tabaci)

(A)dan gejala virus yang ditimbulkan B)

Pengamatan dilakukan bersama sama antara Tim Pelaksana dan Anggota kelompok Tani, secara regular selama masa pertumbuhan Tanaman Kentang. Dari hasil pengamatan tersebut tim pelaksana menyampaikan penjelasan hal hal 
penting yang berkaitan dengan jenis hama hama penting tanaman kentang yang temukan dan menghitung populasi dan intensitas serangan pada masing masing petak . Diamati perbandingan antara tanaman yang diperlakukan dengan larutan dasar pestisida nabati dengan insektisida kimia dan tanpa perlakuan. Dari hasil pengamatan bersama setiap minggu diperoleh bahwa populasi semua hama yang ditemukan pada tanaman kentang yang diperlakukan insektisida kimia selalu terendah, kemudian diikuti oleh perlakuan pestisida nabati, dan yang paling tinggi dijumpai pada control. Dapat dikatakan bahwa pestisida nabati masih berada di bawah kemampuan insektisida kimia, namun berpotensi mampu menekan populasi hama penting pada tanaman kentang .

Analisa Kegiatan Penyuluhan dan Demplot

Kegiatan Penyuluhan dan Demplot pemanfaatan Pestisida nabati dari limbah batang tembakau virginia di Desa Sembalun Bumbung Kecamatan Sembalun Kabupaten Lombok Timur diikuti oleh petani yang merupakan perwakilan dari masing-masing Kelompok .

Proses kegiatan pelatihan ini cukup berhasil berdasarkan indikator kehadiran peserta selama 1 hari penyuluhan, yang dimulai pada jam 10.00 pagi sampai jam 15.00 WITA. Pada awal pelaksanaan kegiatan penyuluhan, pengetahuan dasar peserta tentang hama hama penting tanaman kentang masih beragam ada yang cukup baik ada yang masih rendah, rata-rata tergolong cukup karena hama merupakan masalah utama dalam budidaya kentang dan selalu ditemukan dan dikenali oleh para petani. Bahkan ada beberapa yang sudah mengenal pestisida nabati, walaupun sebagian dari mereka menganggap insektisida kimia yang paling baik dan diandalkan dalam pengendalian hama.

Motivasi peserta untuk mengikuti kegiatan pelatihan cukup tinggi dan terus meningkat sampai akhir kegiatan. Hal ini ditandai dengan tingkat kehadiran peserta yang tidak pernah absen, begitu juga antusiasme peserta yang tinggi selama pelatihan dengan semakin banyaknya peserta yang mengangkat tangan untuk bertanya dan berdiskusi. Sebagian besar peserta pelatihan cukup kritis dalam memberikan ide, gagasan, dan sharing pengalaman dengan fasilitator maupun dengan anggota peserta pelatihan yang lain. Sebagian peserta mempunyai komitmen akan memnafaatkan pestisidnabati sebagai alternative untuk menurunkan ketergantungan penggunaan insektisida kimia , bahkan ada yang akan mencoba mengembangkan pertanian organic dengan memanfaatkan pestisida nabati sebagai alat pengendali utama hama.

Faktor Pendorong dan Penghambat.

Beberapa faktor yang dapat mendukung pemanfaatan pestisida nabati di desa Sembalun Bumbung kecamatan Sembalun kabupaten Lombok Timur adalah sumberdaya alam untuk agrowisata. Desa Sembalun Bumbung merupakan salah satu desa di kecamatan Sembalun kabupaten Lombok Timur yang sebagian besar daerah atau lahan pertaniannya sangat subur, terutama untuk pengembangan hortikultura dataran Tinggi. Semua lahan merupakan lahan iyang intensif ditanami berbagai komoditas hortikultura termasuk kentang . Hanya saja lahan potensial tersebut belum dikelola untuk tujuan agrowisata. Kondisi lahan tersebut sangat potensial untuk pengembangan kentang , termasuk untuk usaha sayuran organic untuk wisata dengan tujuan khusus.

Para peserta juga sangat tertarik dengan diperkenalkan beberapa konsep agrowisata yang berbasis organic, sehingga akan menjadi daya tarik tersendiri bagi wisatawan untuk menikmati agrowisata dan produk organic dengan nilai tambah yang cukup tinggi. Hal tersebut akan berdampak pada peningkatan pendapatan petani di kawasan Sembalun

Keberhasilan dari pelaksanaan kegiatan ini sangat dipengaruhi motivasi dan respon positif masyarakat yang tergabung dalam kelompok tani peserta penyuluhan dan demplot untuk menerima adopsi teknologi Non kimia Sintetik dalam Pengendalian hama, serta mengembangkannya sebagai peluang berusaha dan peluang untuk meningkatkan pendapatan. Disamping itu, dukungan aparat desa dan respon masyarakat di sekitar lokasi sangat baik. Karena kelompok tani peserta pernah mendapatkan pelatihan dari berbagai institusi atas bimbingan instruktur, maka hal ini juga menjadi faktor pendorong, dimana antara peserta dengan instruktur sudah saling mengenal secara emosional. Dengan demikian peserta sangat antusias untuk menerapkan teknologi yang diterapkan untuk mencapai tujuannya yaitu mengurangi ketergantungan terhadap pestisida kimia. 


\section{Kesimpulan}

1. Penyuluhan yang diikuti dengan demonstrasi Plot Pemanfaatan Limbah Batang Tembakau Virginia sebagai Pestisida Nabati dapat meningkatkan minat, pengetahuan dan keterampilan masyarakat petani di Desa Sembalun kecamatan Sembalun kabupaten Lombok Timur sebagai alternative dalam pengendalian hama kutu kebul (Bemisia tabaci) sehingga produksi dan kualitas kentang yang dihasilkan menjadi lebih baik.

2. Masyarakat desa Sembalun mempunyai motivasi yang tinggi untuk mengusahakan tanaman kentang termasuk minat yang cukup tinggi untuk mengndalikan hama kutu kebul (Bemisia tabaci) dengan teknologi non kimia sintetis .

\section{Ucapan Terima Kasih}

Diucapkan terima kasih kepada Universitas Mataram melalui Lembaga Penelitian dan Pengabdian Pada Masyarakat yang telah mendukung pendanaan PNBP untuk kegiatan pengabdian kemitraan Pascasarjana.

\section{Daftar Pustaka}

Fraser, D. G., J. W. Doran, W. W. Sahs and G. W. Lesoing. 1988. Soil Microbial Populations and Activities under Conventional and Organic Management. Journal of Environmental Quality 17: 585-590.

Fransworth, N.R., Henderson, T.O. \& D.D. Soejarto (1987). Plant with Potential molluscicidal actifity. ln:Plant Molluscicides (Eds.: B.O. Acosta \& K.E. Mott). John Wiley and Sons Ltd. Chichester. New York. Brisbane. Toronto. Singapore. p:131-204

Grainge, M. and S. Ahmed. 1988. Handbook of Plants with Pest-Control Properties. John Wiley \& Sons, New York-ChichesterBrisbane-Toronto Singapore. Pp. 99-153.
Harborne, J.B. (1988). Introduction to ecological Biochemistry. Academic Press London. Kloos, H. \& F.S. McCullough (1987). Plant with recognized moluscicidal activity. ln: Plant Moluscicides (Eds.: B.O. Acosta \& K.E. Mott). John Wiley and sons Ltd. Chichester. New York. Brisbane. Toronto. Singapore. p:45-108

Kardinan A. 2001. Pestisida Nabati Ramuan dan Aplikasi. PT. Penebar Swadaya.Jakarta . $187 \mathrm{~h}$.

Lu'aili Addina, Bagyo Yanuwiadi, Zulfaidah Panata Gama dan Amin Setyo Leksono, 2013.., Efek Perpaduan Beberapa Tumbuhan Liar di Sekitar Area Pertanaman Padi Dalam Menarik Arthropoda Musuh Alami dan Hama. El-Hayah Vol. 3, No.2 Maret 2013

McCoy, Steven, 2001. Organic vegetables. A Guide to Production. Departement of Agriculture, Western Australia. 27 p.

Panji, 2009. Pestisida Nabati. Bandung. (online). (http://blog panji/pestisida, diakses $1 \mathrm{Juni}$ 2009)

Reganold, J. P. 1989. Comparison of Soil Properties as Influenced by Organic and Conventional farming Systems. American Journal Alternative Agriculture 3: 144-145.

Rochim dan Rizky, 2002. Sayuran organic Penuhi Keinginan Konsumen, Majalah Hortikultura. Jakarta. H. 24-25.

Sarjan, M. dan Wiresyamsi, A., 1997. Potensi Insektisida Non Kimiawi Sintetis sebagai Pengendali Ulat Kubis Plutella xylostella. Laporan Penelitian Fakultas Pertanian Universitas Mataram.

Sarjan, M., 2004. Potensi Insektisida Non Kimia Sintetik dalam Konservasi Predator Ulat Grayak (Spodoptera litura) pada Tanaman Kedelai. Agroteksos Vol. 13. No. 4. January 2004)

Sarjan, M., 2006a. Intensitas Serangan Ulat Spodoptera litura pada Tanaman Kubis yang Dibudidayakan Secara Organik dan Konvensional (Jurnal HAPETE, Vol 3:1. April 2006)

Sarjan, M., 2006b. Pengelolaan hama Pengisap daun Thrips parvispinus Karny Pada Tanaman cabe Yang dibudidayakan Secara Organik dan Konvensional (Jurnal Penenltian 
Universitas Mataram, Edisi A: Sains dan Teknologi. Vol 2:10. Agustus 2006)

Sarjan, M dan Irwan Muthahanas, 2007a. Pemanfaatan batang dan daun tembakau sebagai bahan pestisida dan kompos pada tanaman sayuran di Lombok Timur. Laporan penelitian BPTP -NTB 2007

Sarjan, M dan Irwan Muthahanas, 2007b. Pemanfaatan batang tembakau virginia sebagai bahan pestisida dan kompos pada budidaya sayuran organik. Laporan penelitian BAPPEDA-NTB 2007

Sarjan, M dkk. 2010. Peningkatan Efektivitas Ekstrak Limbah Batang Tembakau Virginia Sebagai Pestisida Nabati untuk Mengembangkan Teknologi Non Kimiawi Sintesis dalam Perlindungan Tanaman Kedelai. Laporan Penelitian Hibah Strategis Nasional.

Sonyaratri .D, 2006 .Kajian Daya Insektisida Ekstrak Daun Mimba (Azadirachta Indica A.Juss) Dan Ekstrak Daun Mindi (Melia Azedarach L.) Terhadap Perkembangan Serangga Hama Gudang Sitophilus Zeamais Motsch. Fakultas Teknologi Pertanian Institut Pertanian Bogor. Bogor.

Suryanto, A, T.Himawan dan Sitawati, 2003. Budidaya sayuran organic melalui pendekatan ekologi di kebun percobaan Cangar. Pada Pelatihan Dosen-dosen PN-PTS se- Indonesia. Petanian Berkenaljutan Untuk meningkatkan Kesejahteraanh Masyarakat. Malang 12-21 Juli 2003.

Untung, K., 1993. Konsep Pengendalian Hama Terpadu. Andi Offset, Yogyakarta.

Tamba, M., 2016. Strategi Pengembangan Kawasan Komoditas Unggulan Hortikultura. Dirjen Hortikutura Kementan. Sinartani edisi 24 Feb-1 Maret 2016. No.3644 Th XLVI.Gramedia Jakarta.

Wang, Y. and C. Chao. 1995. The Effect of Organic Farming Practices on the Chemical, Physical and Biological Properties of Soil in Taiwan. In: Sustainable Food Production in the Asian and Pacific Region. Food and Fertilizer Technology Center for the Asian and Pacific Region.

Wood, Maria, L. Chavez and Don Comis, 2002. Organic grows on America. Agricultural Research U.S. Departementb of Agriculture. $19 \mathrm{p}$. 